\title{
EARLY COMPLICATIONS OF THE TRANSOBTURATOR TAPE AND MINI SLING PROCEDURE
}

\author{
Cuneyt Eftal TANER, Gulin OKAY
}

Ministery of Health Tepecik Education and Research Hospital, 4th Department of Obstetrics and Gynecology, İzmir

\section{SUMMARY}

Aims: To compare perioperative and postoperative complications of mini sling and transobturator tape (TOT) operations in the surgical treatment of female urinary incontinence.

Material and methods: After the urodynamic evaluation of the patients with stres urinary incontinence or cases with mixed urinary incontinence with significant stress factor,130 cases who underwent TOT procedure and 151 cases who underwent mini sling procedure were compared in terms of complications..The duration of follow up in the TOT group was 6-30 (mean 18) months and it was 6-21 (mean 13,5) months in the mini sling group

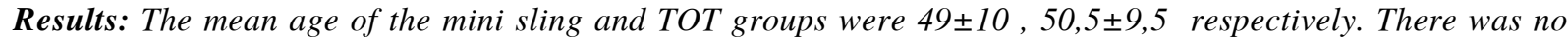
intraoperative bladder or urethral perforation.

There were no major vessel or nerve injury in both groups. In 5 (3.8\%) cases of the TOT group and 6 cases (4\%) of the mini sling group, intraoperative vaginal sulcus perforation developed and mucosal defects immediately sutured. Mesh extrusion was detected in $6(4.6 \%)$ and 18 (10.9\%) cases of the TOT and mini sling group, respectively. There was a statistically significant difference about mesh extrusion (p: 0.036). Ten patients (6.1\%) and eight cases (6.15\%) had de novo urge incontinence responsed to medical theraphy in the post-operative follow-up in the mini sling and TOT groups, respectively. Two patients (1.2\%), who underwent the mini sling procedure, required sling section due to prolonged bladder outlet obstruction. Significant infection complication due to operation was not detected. Three and one cases complained of thigh pain in the TOT and mini sling group, respectively.

Conclusions: Mini sling procedure, when compared with suburethral tape, had similar complication rates except relatively high mesh erosion rates with comparable success rates. All cases should be carefully followed for late complications.

Key words: complication, mini sling, transobturator tape

Journal of Turkish Society of Obstetrics and Gynecology, (J Turk Soc Obstet Gynecol), 2014; Vol: 11, Issue: 1, Pages: 14-20

\section{TRANSOBTURATOR TAPE VE MINI SLING OPERASYONLARININ ERKEN DÖNEM KOMPLİKASYONLARI}

\section{ÖZET}

Amaç: Transobturator bant tekniği (TOT) ve mini sling prosedurunde görülen intra ve postoperatif komplikasyonların karşılaştırılması.

Gereç ve yöntemler: Stres üriner inkontinansı veya miks inkontinansı olup stres faktörü ön planda bulunan olgularda ürodinamik değerlendirmeler tamamlandlktan sonra TOT uygulanan 130 olgu ile mini sling uygulanan 151 olgunun komplikasyonları karşılaştırıldı. TOT grubunda takip süresi 6-30 ay (ortalama 18 ay) ve mini sling grubunda postoperatif takip 6-21 ay (ortalama 13,5 ay) sürdü.

Address for Correspondence: Dr. Gülin Okay. İzmir Tepecik Eğitim ve Araştırma Hastanesi, Kadın Hastalıkları ve Doğum Hastanesi, Yenişehir, İzmir Phone: + $90(505) 6540922$

e-mail: gulinokay@hotmail.com

Received: 15 September 2013, revised: 26 October 2013, accepted: 29 October 2013, online publication: 31 October 2013 
Bulgular: 130 TOT operasyonu uygulanan olgunun yaş ortalaması 50,5 \pm 9,5 (29-72), mini sling uygulanan hastaların

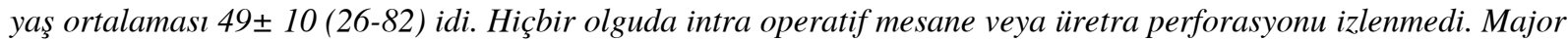
damar veya sinir yaralanması her iki grupta da izlenmedi. TOT yaplan olguların 5 inde (\%3,8), mini sling yapılanların ise 6 sinda (\% 4) intraoperatif vajinal sulkus perforasyonu gelişti ve hemen suture edildi. TOT grubunda 6 (\%4,6) olguda, mini sling grubunda ise 18 (10.9\%) olguda anlaml olarak daha fazla mesh erozyonu tespit edildi (p: 0.036). Mini sling grubunda 10 (6.1\%) olguda, TOT grubunda ise 8(\%6.15) olguda tıbbi tedaviye yanıt veren de novo urge inkontinans saptand. Mini sling uygulananlardan 2 olguda kalıcı üriner retansiyon gelişmesi üzerine postoperatif dönemde gergin mesh kesildi. Her iki grupta da operasyona bağll belirgin enfeksiyöz komplikasyon izlenmedi. TOT ve mini sling grubunda sirasıla üç (\%2,3) ve bir (\%0.6) olgu uyluk ă̆rısından yakındı.

Sonuç: Subüretral tape ile karşılaştırıldı̆̆ında mini sling prosedürü nispeten daha fazla mesh erozyonu görülmesi dışında benzer komplikasyon oranları ile kıyaslanabilir başarı oranlarına sahiptir. Geç postoperatif komplikasyonlar açısından olgular dikkatli takip edilmelidir.

Anahtar kelimeler: komplikasyon, mini sling, transobturator tape

Türk Jinekoloji ve Obstetrik Derneği Dergisi, (J Turk Soc Obstet Gynecol), 2014; Cilt: 11, Sayl:1, Sayfa: 14-20

\section{INTRODUCTION}

Stress urinary incontinence (SUI) is the most common type of the female urinary incontinence and it is known as involuntary urine leakage with activities which increase abdominal pressure such as coughing, sneezing, laughing and lifting. Genuine SUI is defined as urodynamically proven involuntary loss of urine occuring at the absence of the detrusor muscle contraction, the intravesical pressure exceeds the maximum urethral pressure. It is also seen as a result of hypermobility of the vesicourethral segment caused by pelvic floor weakness.

Primary aim in SUI surgery is to maintain continence with minimal morbidity. There have been over 100 procedures described in the last century to treat female SUI. The short term success rates of these procedures vary between $73 \%-96 \%$ according to surgical technique. Generally, the first surgical approach has the highest success chance ${ }^{(1)}$. Therefore, the surgical technique should be effective, it should cause minimal perioperative morbidity and postoperative sequel and so the effectivity of the technique should not decrease in the long term. General health condition, urethral mobility, preoperative urodynamic parameters, surgical experience and possible complications of the surgical techniques must be taken into account while deciding the operation type(2).

Transobturator tape (TOT) operation was described by Delorme in $2001^{(3)}$. After the description of outsidein TOT operation in 2001, it has been used commonly as a secure, effective and minimally invasive technique (4). TOT operation is an easy technique to learn and carry out in SUI treatment and its cure rates are between $80 \%-92 \%$ but it has shown that this effect decreases over time ${ }^{(5,6)}$. TOT procedure can be placed via outside-in and inside-out approach by avoiding the blind dissection in retropubic area. As a conclusion of that, TOT procedure has less risk of visceral injury. Third generation midurethral slings were described as mini sling in 2006 and these short slings can be applied via single vaginal incision and provide suburethral hammock-like supportive layer. As a result of avoiding blind dissection at the retropubic and inguinal area, the effectivity of the mini slings is equal to midurethral slings with decreased incidence of perioperative morbidity $(7,8)$. In addition, the other advantages of the mini slings are providing tolerance to application under local anesthesia, decreasing postoperative pain incidence, shortening hospitalization duration, having short-term recovery and returning to daily life earlier $(8,9)$.

In this study, we reviewed the perioperative and postoperative complications of the mini sling and TOT operations performed in our clinic and discussed these techniques in terms of complications.

\section{MATERIAL AND METHODS}

We have studied the cases retrospectively to whom TOT and mini sling operations were performed in İzmir Tepecik Education and Research Hospital, Turkey between the years 2008-2012.Preoperatively written approval of all patients were obtained and scanning of 
all the files and postoperative follow-ups were completely performed. The cases who have neglected the follow-ups were reached via telephone and complaints were asked. The study groups were made up of the 130 cases to who underwent TOT operation because of SUI and mixed urinary incontinence with predominant SUI between the years 2008-2010 and 151 patients who underwent mini sling procedure between the years 2011-2012. Detailed medical history and physical examinations of all cases were recorded. Subsequently complete blood count, urine examination, suprapubic ultrasonography, cough stres test (Marshall, Bonney, Q tip test) and cystometry dynourodynamic system, Aymed) were performed to all cases preoperatively and postoperatively at the 6 months intervals. The aforementioned methods were used for differential diagnosis of urinary incontinence. Preoperatively and postoperatively the same methods were used for evaluating success and for the diagnosis of de novo symptoms. Residue urine amount of the cases, who were suspected about urinary retention, was measured via catheter or pelvic ultrasonography. The cases who had fertility desire, extra gynecopathology, advanced systemic disease, mixed incontinence with predominant urge incontinence, women with pathologies requiring hysterectomy were excluded from the study.

We provided suburethral support to 130 patients with outside-in Safyre TOT material and to 151 cases with Ophira mini sling system (Promedon, Argentina). All the operations were performed by the same operator and different research assistants. TOT operations were performed under spinal anesthesia. $86,1 \%$ of the mini sling operations were performed under local anesthesia with intravenous sedation support and 13,9\% of them were performed under spinal anesthesia. All cases had single dose infection prophylaxis with a first generation cephalosporin. Intraoperatif complications of the cases were recorded to operation documents. Routine cystoscopy wasn't performed. The patients who were suspected about urinary retantion, residue urine was evaluated by ultrasonography. Follow-ups were planned at postoperative 1 month and 6 months intervals. The complications were recorded and results were revised. For TOT operations, the patients were placed in the gynaecological position with thighs in hyperflexion and $120^{\circ}$ angle obtained between abdomen and limbs. The anterior middle vertical vaginal wall was incised at the level of $1 / 3$ middle part of the urethra. This step was followed by introducing fine dissection scissors through the initial dissection path towards the ischiopubic ramus, trocars were pushed along the preformed dissection canal on the plane which is between the clitoris and the urethra bilaterally at the genitofemoral fold with inside-out technique. TOT material was placed. After creating 1-2 $\mathrm{mm}$ tension free space between tape and the urethra, the vaginal incisions were closed. Foley catheter was placed for 24 hours after the operation.

In the mini sling procedure, after emptying the bladder with a catheter, using $10 \mathrm{ml}$ of lidocaine $\mathrm{HCl} 20 \mathrm{mg} / \mathrm{ml}$, epinephrine HCI $0.0125 \mathrm{mg} / \mathrm{ml}$ solution (5 ampuls), injected at the midurethra towards the vaginal fornix, advancing $2 \mathrm{~cm}$ through the internus muscles. $1 \mathrm{ml}$ midazolam was given intravenously for sedation to whom the procedure was performed under local anesthesia. A vertical 1-cm long vaginal incision was performed at $1 \mathrm{~cm}$ distance from the external urethral meatus. Minimal vaginal dissection was performed laterally toward the ascending ramus of the ischiopubic bone, preserving the endopelvic fascia. The delivery trocar was introduced through the small vaginal incision, guided by the surgeon's index finger previously introduced at the vaginal fornix to avoid vaginal wall perforation. Once the needle was felt at the fornix, the tip was introduced toward the obturator internus muscle at the level of the arcus tendineus fascia. When half of the mesh was within the incision, the deployment button on the needle handle was pressed and the mini sling was kept in place by the self-anchoring fishbone columns. The same maneuvers were repeated on the other side. To avoid undue tension, a Metzenbaum scissors was positioned between the urethra and the mesh in order to provide a tension free $2 \mathrm{~mm}$ space. The vaginal wall re-sutured.

Statistical Package for the Social Sciences (SPSS) 21 and Medcalc 9 (Acacialaan 22, B-8400 Ostend, Belgium) programs were used in the analysis of the datum. For the analysis of the convenience of quantitative datum to normal distribution KolmogorovSmirnov test, Shapiro-Wilk test and Coefficient variations were analysed by being taken into consideration; and parametric methods were used in the analysis of the variations that have normal distribution, and nonparametric methods were used in the analysis of the variations that do not have normal 
distribution. In the comparison of 2 independent groups, Independent-Samples $\mathrm{T}$ test and Mann-Whitney $\mathrm{U}$ tests were used. While, for the comparison of two dependent groups Wilcoxon Signed Ranks Test was used. In the comparison of categorical datum Pearson Chi-Square test was used. For the determination of the most important risk factor of the categorical significant risk factors odds ratio was used. ROC (Receiver Operating Curve) analysis was made in estimating the Cut-off values. The quantitative values were shown in the tables as mean \pm std. (Standard deviation) and median \pm IQR values. And the categorical values were shown as n(number) and percentages (\%). The datum were analysed in the $95 \%$ confidence level, and $p$ value was accepted as significant if less than 0,05 .

\section{RESULTS}

The number of cases who underwent TOT and mini sling operations in the 2 years period and followed up postoperatively were 130 and 151 , respectively. The mean age of the cases for TOT and mini sling groups were 50,5 $\pm 9,5$ (29-72) and 49 \pm 10 (26-82), respectively. The patients in the TOT group completed mean 18 months follow-up (min.6- max.30 months) and the patients in the mini sling group completed mean 15 months follow-up (73 of them 6 months, 78 of them 1 year). No major intraoperative complications (e.g. major vascular injury, bladder or urethra perforation, nerve damage and infection) were recorded. Hemorrhagia over $200 \mathrm{ml}$ occured in 4 cases $(3,1 \%)$ in only TOT group. Two units of erythrocyte suspension were given to one patient (Hemoglobine: 7,2 mg/dl). Intraoperative vaginal sulcus perforation occured and sutured immediately in 5 cases $(3,8 \%)$ and in 6 cases in the TOT and mini sling group, respectively. We determined mesh erosions at the postoperative $1^{\text {th }}$ and $6^{\text {th }}$ months follow-up in $6(4,6 \%)$ and $18(11,8 \%)$ cases in the TOT and mini sling groups, respectively. In these cases, vaginal mucosa debrided, mesh partially excised and vaginal mucosa of the debrided area resutured with polyglycolic acid suture material. None of the cases developed postoperative urinary retention in the TOT group but 5 cases developed urinary retention in the mini sling group. The cases who had residual urine volume over $100 \mathrm{ml}$ or who developed glob vesicale required catheterization and controlled after one week. The two cases, who developed urinary retention and catheterized postoperatively in the mini sling group, re-operated fort he excision of the tight mesh after the $8^{\text {th }}$ and $19^{\text {th }}$ day of operation. Transient dysuria was determined in 10 and 5 cases in the TOT and mini sling groups, respectively. Three patients in the TOT group and one patient in the mini sling group complained of groin pain. De novo urge incontinence determined in 8 and 10 cases in the TOT and mini sling groups at the postoperative follow-ups, respectively and these cases were treated successfully with anticholinergic drugs. When we analysed the complications in both study group,we didn't determine any significant difference between the groups in terms of the other complications, except mesh erosion ( $p$ : 0,036) (Table I).

Table I: Complications in the TOT and mini sling groups.

\begin{tabular}{lccc}
\hline Complications & $\begin{array}{c}\text { TOT } \\
(\mathbf{n}=\mathbf{1 3 0})\end{array}$ & $\begin{array}{c}\text { MINITOT } \\
(\mathbf{n}=\mathbf{1 5 1})\end{array}$ & $\mathbf{P}$ \\
\hline Transient dysuria & $10(\% 7.69)$ & $5(\% 3,3)$ & 0,114 \\
Mesh erosion & $6(\% 4.6)$ & $18(\% 11.9)$ & 0,036 \\
Hemorrhage over 200ml & $4(\% 3.07)$ & $0(\% 0)$ & - \\
Groin pain & $3(\% 2.3)$ & $1(\% 0.6)$ & 0,25 \\
Urinary retention & $0(0 \%)$ & $5(\% 3.3)$ & - \\
Intraoperative vaginal & & & \\
sulcus perforation & $5(\% 3.84)$ & $6(\% 3.9)$ & 0,955 \\
De novo urge incontinence & $8(\% 6.15)$ & $10(\% 6.6)$ & 0,875 \\
Chi-Square Test & & & \\
\hline
\end{tabular}

\section{DISCUSSION}

It is considered that none of the surgical procedures in female SUI defined up to today, provided curative treatment and all of them have some complications (10). However, in the recent years remarkable developments occured in surgical techniques in this field.

The most serious complication of the TOT operations is hemorrhage and this condition generally originates from the urethrovaginal dissection of the venous plexus (11). In our study hemorrhage over $200 \mathrm{ml}$ developed in 4 cases $(3,07 \%)$ in the TOT group and only one of them required erythrocyte suspension transfusion. None of the cases in the mini sling group developed hemorrhage over $200 \mathrm{ml}$. Afşar et al. reported that only one patient required transfusion and haematoma didn't occur in this case ${ }^{(12)}$. They reported the rate of hemorrhage over $200 \mathrm{ml}$ as 3,3\% and this rate overlaps 
with the findings of Abdel-Fattah et.al ${ }^{(13)}$.

Gambirasio et.al. performed TOT procedure to 233 cases and followed them for 27 months. Hemorrhage over $200 \mathrm{ml}$ occured in the $5,2 \%$ of the cases but none of them developed haematoma and required transfusion. Various hemorrhage rates between $0,83 \%$ - 5,4\% were reported in different case series about the TOT procedure $^{(13,14)}$.

The theoretical advantage of the mini sling procedures is the decrease in the rates of serious iatrogenic lacerations. Walsh et al. analysed 10 study and reported that internal pudendal artery laceration occured and required radiological embolization to provide homeostasis in only one patient ${ }^{(15)}$.

De novo urge incontinence effects the life quality negatively and de novo urge incontinence rate was low $(4,2 \%)$ in the TOT group in the study of Afşar et al. and this rate was similar with the literature(12,16,17). In our study, we reported de novo urge incontinence in $8(6,15 \%)$ and $10(6,6 \%)$ cases in the TOT and mini sling groups, respectively.

As a complication, de novo urge incontinence occurs rarely after the TOT operations and it proves that TOT operation has minimal obstructive effect. Rougmeguere et al. reported de novo urge incontinence rate as 2,5\%, Krauth et al. reported 5,2\% de novo urge incontinence rate after 3 months follow-up ${ }^{(18,14)}$. Göynümer et al. established de novo urge incontinence in $3 \%$ of the cases $^{(19)}$.

Barber et al. operated 263 cases with the mini sling and tension-free vaginal tape (TVT). They cut the sling or performed urethrolysis to recruit voiding dysfunction or persistent urge incontinence in 2 cases $(1,5 \%)$ in mini sling group and 3 cases $(2,4 \%)$ in the TVT group (20).

Djehdian et al. compared the Ophira mini sling and the Unitape TOT procedure in their investigation. They reported de novo urge incontinence in 3 cases $(10,3 \%)$ in the mini sling group and none in the Unitape group (21).

It is considered that the usage of monofilament macropore polypropylene mesh is the most important factor to prevent vaginal erosion. During learning process complication rates decreases and the management of the complications become easier with surgical experience ${ }^{(12)}$. In our study, all the operations were performed by the same surgeon and by the help of different assistants under the supervision of the aforementioned surgeon. So that, the effect of the learning curve to mesh erosion rate can not be evaluated. Mesh erosion is directly related with biomechanic properties, wound healing, local factors as infection and also surgical technique. It is known that defective tissue healing have seen frequently with the usage of multifilament, micropore suburethral tapes. Age, body mass index, previous vaginal surgery or simultaneously performed vaginal surgery are not significant risk factors.

After the partial excision of the eroded mesh,the cases can stay continent. Complet excision of the mesh can be done in case of an infection. But complet excision usually leads to recurrence of the SUI symptoms ${ }^{(22)}$. Afşar et al. reported that $3,3 \%$ of the patients who underwent the TOT operation, developed early vaginal erosion complication ${ }^{(12)}$. Our early vaginal erosion rates were $4,6 \%$ (6 cases) and $11,9 \%$ (18 cases) in the TOT and mini sling groups, respectively. Erosion rates were significantly high in the mini sling group (p: 0,036). Right along with the individual factors, sling material and surgical technique are important factors leading to vaginal erosion. Inadequate suturation of the vaginal incision, infection, rejection of the sling material, early sexual intercourse and vaginal perforation may cause vaginal erosion. Vaginal erosion incidence after incontinence surgery varies between $0,7 \%$ and $13,8 \%(23)$. Göynümer et al. studied 66 patients who undergone TOT operations in their prospective study and after an average of 9 months after the operation $24,2 \%$ of patients had reported limb pain, $6,1 \%$ had vaginal erosion, $3 \%$ developed de novo urgency, $7.6 \%$ had obstruction and 4,5\% suffered from

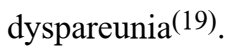

Mesh erosion has become an important complication after the vaginal usage of synthetic meshes and mesh erosion rates are taken into account in the usage of the new procedures in the treatment. Walsh et al. reported a review of outcomes following TVT-Secur published to date (n:1178 cases from 10 studies) and the incidence of mesh exposure was $2,4 \%(16)$.

Djehdian et al. reported that in the Ophira group, 4 patients $(16,8 \%)$ experienced mesh vaginal erosion less than $1,5 \mathrm{~cm}$. Three of them underwent ambulatory mesh resection of the exposed area, and other one received treatment with local estrogen. Three patients had urinary retention, treated with mesh resection or cut, and one had spontaneous improvement. In the 
Unitape group one patient $(6,7 \%)$ had mesh erosion, with ambulatory resection and 4 patients had leg pain (21).

Bladder perforation, another rare complication, was reported $0,5 \%(3 / 604)$ of the cases who underwent the TOT procedure in the study of Krauth et al ${ }^{(14)}$. Two of them had high grade cystocele. Minaglia et al. reported bladder perforation in the TOT operation in three cases and two of them had previous pelvic organ prolapse (POP) surgery(24). Cystoscopy procedure can be performed to the cases who had the history of previous POP surgery or who undergone the TOT and POP surgery simultaneously. It can be considered that the reason why we didn't see any bladder perforation in both groups was this: we excluded the patients with high grade cystocele in our study.

The number of studies which compare standart midurethral slings (SMUS) and mini slings, is scarce. Mostafa et al. compared the short term results of the mini sling (Ajust) and SMUS (TVT-O) in their multicenter prospective randomised study. No significant difference between groups were reported in terms of perioperative complications. Mini sling group had high de novo urgency rate but there were no differences between the groups statistically $(21,7 \%$ vs $8,8 \%$ ). Vaginal erosion rates were $2,9 \%$ and $1,4 \%$; voiding difficulty rates requiring uriner catheterization were $11,8 \%$ and $4,3 \%$ in the TVT-O and mini sling groups, respectively. In our study, we reported no significant difference between the groups in terms of complications, as reported in the study of Mostafa et $\mathrm{al}^{(8)}$.

De Ridder et al. compared the Miniarc (n:75) and the Monarc (n:56) procedures. The only major intraoperative complication reported in the Monarc group was a bleeding $>500 \mathrm{~cm} 3$ in a case. In both groups, one intraoperative vaginal perforation occured. They also reported de novo urgency at 6 weeks after surgery as $20 \%$ and $9 \%$ in the TOT and mini sling groups, respectively $(\mathrm{p}: 0,14)^{(25)}$. In our study, vaginal sulcus perforation developed in 5(3,84\%) and 6(3,9\%) cases in the TOT and mini sling group, respectively. Abdel-Fattah et al. reported a meta-analysis of 9 randomised controlled trials comparing mini slings and SMUS. Mini slings were associated with significantly less postoperative groin pain but repeat continence surgery, de novo urgen incontinence and tape erosions were significantly higher in the mini sling group ${ }^{(7)}$. Although we found no significant difference between the groups, de novo urgency incontinence rate was higher in our mini sling group. The higher incidence of de novo urgency associated with mini slings can be explained by the recommended positioning of mini sling is in close proximity to,or in contact with, the urethra, which may lead to irritation symptoms $(26,27)$.

As a conclusion, mini slings seem to be a valid option in SUI treatment with their low morbidity rates reported in compared studies. Because of the high mesh erosion rates in our study and in the literature, developing technology could be applied on the meshes in the market and large, well-designed, prospective randomised controlled trials, with long term followup, which compare SMUS and mini slings are required.

\section{REFERENCES}

1. Franco AVM, Fynes MM. Surgical treatment of stress incontinence. Current Obstet Gynecol 2004;14:405-11.

2. Wall LL. Urinary stress incontinence. In: Rock JA, Jones HW, eds. Telinde's Operative Gynecology. Philadelphia: Lippincott Williams \& Wilkins Company, 2003.

3. Delorme E, Droupy S, De Tayrac R, Delmas V. Transobturator tape Uratape, a new minimally invasive treatment for female urinary incontinence. Prog Urol 2003;13:656-9.

4. Delorme E, Droupy S, de Tayrac R, Delmas V. Transobturator Tape (Uratape(r)): A new minimally-invasive procedure to treat female urinary incontinence. Eur Urol 2004;45(2):2037.

5. Giberti C, Gallo F, Cortese P, Schenone M. Trans-obturator tape for treatment of female stress urinary in-continence: objective and subjective results after a mean follow-up of two years. Urology 2007;69(4):703-7.

6. Deval B, Ferchaux J, Berry R, Gambino S, Ciofu C, Rafii A, et al. Objective and subjective cure rates after trans-obturator tape (OBTAPE) treatment of female urinary incontinence. Eur Urol 2006;49(2):373-7.

7. Abdel-Fattah M,Ford JA,Lim CP, Madhuvrata P. Singleincision mini-slings versus standard midurethral slings in surgical management of female stress urinary incontinence: A meta-analysis of effectiveness and complications. Eur Urol 2011;60(3):468-80.

8. Mostafa A, Agur W, Abdel-All M, Guerrero K, Lim C, Allam $\mathrm{M}$, et al. A multicentre prospective randomised study of singleincision mini-sling (Ajust) versus tension-free vaginal tape- 
obturator (TVT-O) in the management of female stress urinary incontinence: pain profile and short-term outcomes. Eur J Obstet Gynecol Reprod Biol 2012;165(1):115-21.

9. Hinoul P, Vervest HAM, Boon J, Venema PL, Lakeman MM, Milani AL, et al. Randomized, controlled trial comparing an innovative single incision sling with an established transobturator sling to treat female stress urinary incontinence. J Urol 2011;185(4):1356-62.

10. Ward KL, Hilton P; UK and Ireland TVT Trial Group. A prospective multicenter randomized trial of tension-free vaginal tape and colposuspension for primary urodynamic stres incontinence: two-year follow-up. Am J Obstet Gynecol 2004; 190(2):324-31.

11. Geçit İ, Pirinççi N, Güneş M, Benli E, Şahin MA,Taken K, et al. Stres inkontinans tedavisinde transobturator tape (TOT) ile transvaginal tape'in (TVT) etkinliğinin ve komplikasyonlarının karşılaştırılması. Van Tıp Dergisi 2011;18(4):173-80.

12. Afşar S, Üyetürk U, Dilli A, Haytoğlu E, Yiğit A, Kemahlı E. The effectiveness and complications of transobturator tape operation: analysis of 120 cases. Abant Med J 2012;1(3):1258.

13. Abdel-Fattah M, Ramsay I, Pringle S, Bjornsson S, Hardwick $\mathrm{C}$, Tierney $\mathrm{J}$, et al. Transobturator suburethral tape in the management of urinary incontinence: success, safety and impact on sexual life. Gynecol Surg 2007;4(4):267-73.

14. Krauth JS, Rasoamiaramanana H, Barletta H, Barrier PY, Grisard-Anaf M, Lienhart J, et al. Sub-urethral tape treatment of female urinary incontinence--morbidity assessment of the trans-obturator route and a new tape (I-STOP): a multi-centre experiment involving 604 cases. Eur Urol 2005;47(1):102-6.

15. Walsh CA.TVT-Secur mini-sling for stress urinary incontinence: a review of outcomes at 12 months. BJU Int 2011;108(5):652-7.

16. Coyne KS, Sexton CC, Irwin DE, Kopp ZS, Kelleher CJ, Milsom I. The impact of overactive bladder, incontinence and other lower urinary tract symptoms on quality of life, work productivity, sexuality and emotional well-being in men and women: Results from the EPIC study. BJU Int 2008;101(11): 1388-95.

17. Holmgren C, Nilsson S, Lanner L, Hellberg D. Long-term results with tension-free vaginal tape on mixed and stress urinary incontinence. Obstet Gynecol 2005;106(1):38-43.
18. Roumeguere T, Quackels TH, Bollens R, De Groote A, Zlotta A, Vanden Bossche M, et al. Transobturator vaginal tape (TOT) for female stress incontinence: One year follow-up in 120 patients. Eur Urol 2005;48(5):805-9.

19. Göynümer FG, Yücel N, Uslu GZ, Açış R, Türkgeldi E, Durukan B. The initial experience of a training hospital on TOT. J Turkish-German Gynecol Assoc 2009;10(2):80-3.

20. Barber MD, Weidner AC, Sokol AI, Amundsen CL, Jelovsek JE, Karram MM, et al. Single-incision mini-sling compared with tension-free vaginal tape for the treatment of stress urinary incontinence: a randomized controlled trial. Obstet Gynecol 2012;119(2 Pt 1):328-37.

21. Djehdian L, Araujo M, Takano C, et al. Randomised trial of Ophira mini-sling system and Unitape for the treatment of stress incontinence in women. First experiences after a followup of 6 months. Int Urogynecol J 2010;21(Suppl 1):1-428.

22. Abdel-Fattah M, Sivanesan K,Ramsay I, Pringle S, Bjornsson S. How common are tape erosions? A comparison of two versions of the transobturator tension-free vaginal tape procedure. BJU Int 2006;98(3):594-8.

23. Meschia M, Bertozzi R, Pifarotti P, Baccichet R, Bernasconi F, Guercio E, et al. Peri-operative morbidity and early results of a randomised trial comparing TVT and TVT-O. Int Urogynecol J Pelvic Floor Dysfunct 2007;18(11):125761.

24. Minaglia S, Ozel B, Klutke C, Ballard C, Klutke J. Bladder injury during transobturator sling. Urology 2004;64(2): 3761-2.

25. De Ridder D, Berkers J. Single incision mini-sling versus a transobutaror sling: a comparative study on MiniArc and Monarc slings. Int Urogynecol J Pelvic Floor Dysfunct 2010; 21(7):773-8

26. Assassa P, Moran P, Duckett J, Bsug B. Stress incontinence surgery in the UK. Pre-operative work up and intra-operative complications. Analysis of the British Society of Urogynaecology database. Int Urogynecol J 2010;21(Suppl 1):1-428.

27. Meschia M, Barbacini P, Baccichet R, Buonaguidi A, Maffiolini M, Ricci L, et al. Short-term outcomes with the AjustTM system: a new single incision sling for the treatment of stress urinary incontinence. Int J Urogynaecol 2011;22 (2):177-82. 